TRABALHO COMPLETO DE OBSTETRICIA

$1^{\circ}$ LUGAR

\title{
Alteraçoes Ultra-estruturais do Glomérulo na Pré-eclâmpsia
}

\author{
Ultrastructural Glomerular Alterations in Preeclampsia
}

Suzana Maria Pires do Rio, Victor Hugo de Melo, Pérsio Godoy, Mitiko Yokota

\begin{abstract}
RESUM0
Objetivos: identificar as alterações ultra-estruturais glomerulares em pacientes com préeclâmpsia grave, assim como avaliar a evolução destas lesões e sua relação com o momento de realização da biópsia renal.

Métodos: dentre as 72 gestantes com sindrome hipertensiva que se submeteram à biópsia renal no puerpério, em 39 o material obtido mostrou-se adequado para exame à microscopia eletrônica de transmissão, assim distribuidas: 25 eram portadoras de pré-eclâmpsia pura e 14 tiveram diagnóstico de pré-eclâmpsia superposta à hipertensão arterial crônica. As apresentações morfológicas estiveram representadas por rim normal, edema das células endoteliais, expansão do mesângio, interposição mesangial, depósitos subendoteliais $e$ fusão dos pés dos podócitos.

Resultados: as alterações mais freqüentes nos dois grupos foram os depósitos subendoteliais e a fusão dos pés dos podócitos. O edema da célula endotelial ocorreu em $84 \%$ das pacientes com pré-eclâmpsia pura e 92,9\% das pacientes com pré-eclâmpsia superposta. Não foi observada associação entre a gravidade da doença e a intensidade do edema da célula endotelial. Verificou-se tendência de interposição mesangial em pacientes biopsiadas após o sétimo dia pós-parto. A fusão dos podócitos apresentou associação significativa com a proteinúria de 24 horas.

Conclusões: as alterações glomerulares citadas representam espectro de lesões complexas e dinâmicas que, em conjunto, constituem as caracteristicas ultra-estruturais da préeclâmpsia, que não deve, pois, ser identificada somente pela presença do edema da célula endotelial.
\end{abstract}

PALAVRAS-CHAVE: Microscopia eletrônica. Edema da célula endotelial. Pré-eclâmpsia.

Publicado como trabalho completo na Rev Bras Ginecol Obstet 2004; 26: 185-92. 